\title{
Foreign Language \\ in a Non-Linguistics Higher School: Optimal Means of Control
}

\author{
Vita V. Vonog* \\ Siberian Federal University \\ 79 Svobodny, Krasnoyarsk, 660041, Russia
}

Received 22.05.2017, received in revised form 10.10.2017, accepted 13.10.2017

The article is devoted to author's observations and research aimed at looking for an appropriate means of control that corresponds to student-centered approach in teaching English in a Higher School. The target audience is students of non-linguistics specialties who are taught to take Cambridge international exams in terms of Russian academic excellence program. The efforts of Siberian Federal University have been aimed at increasing the number of English classes and organizing the system of internal and external testing, i.e. Preliminary English Test (PET), First Certificate in English (FCE) and Test of Legal English Skills (TOLES). Due to such methods of research as prognostic simulation and experimental learning the author collected data connected with the system of evaluating students' progress by means of mock exams. This choice is reasonable as the quality and effectiveness of teaching increase. As a result it causes a higher motivation among students of non-linguistics specialties to English language and reduces overall time to achieve the planned learning outcomes.

Keywords: Means of control, English, mock exams, assessment, Cambridge exams syndicate, Russian academic excellence program.

DOI: 10.17516/1997-1370-0160.

Research area: language education, education science.

\section{Introduction}

Currently Siberian Federal University (SFU) carries out a number of activities aimed at creating a bilingual environment and organizing training and compulsory testing of students for English proficiency according to the internationally recognized system in the framework of the Russian academic excellence program among the world's leading scientific and educational centers (SFU, 2016).

Currently the role of subject "Foreign language" has been reconsidered to a great extent due to development of student's professional awareness of non-linguistics specialty development of modern professional individual as "an individual realizing their full potential in profession, by means of profession, understanding the values of this profession" (Yarotskaya, 2016: 81) This point of view is supported by other scientists who believe that a modern technical University must train professionals who apart from having a high special competence, also have the understanding of the common cultural

(c) Siberian Federal University. All rights reserved

* Corresponding author E-mail address: vonog_vita@mail.ru 
issues. (Sergeyeva, S.V., Voskrekasenko, O.A., 2016: 485).

Due to globalization, higher education internationalization, student exchange programs and academic mobility and international projects students and academics tend to search for new ways of studying and teaching English language as means of academic and professional communication. The possibility comes true through redesign of the academic units (Cheah, Ch. Y.J., Chen, P.H., Ting, S.K., 2005: $105)$ in teaching the subject "Foreign language" and balanced forms of learning and forms of control.

Focusing on what the learner can do means building on success rather than concentrating on deficits. There are a number of definitions for this term in a control problem methodical literature. Generally, it is understood as a determination of reference level, students obtain for period of studying. Information, we receive during control, allows academics and student to reach decisions of further activities.

Control of learning outcomes is an obligatory component of studying process. Consideration of control as a regulator of activities, that provides predictable results, allows state the obvious recurrence of the regulation process, associated with the need to identify, measure, assess and, if necessary, correct the functional state of the controlled system.

From this perspective, it is obvious that one of actual problem is current monitoring and quality control of students' knowledge. It is reasonable to apply traditional control methods, such as questioning, dictation, test, translation and interpretation with alternative methods and it allows students: 1) to act not just as object, but as subject of studying; 2) to develop greater autonomy in teaching; 3) to have clearer vision of foreign language studying purpose and build own strategy of mastering language.

\section{Theoretical Framework}

Analysis of studies devoted to the quality of evaluating professional students training, is evidence of elaboration in this such general didactic issues as the control in the system of developing education (Ermakov, 2006), the system control methods as a means to enhance learning (Brichev, 2006), test quality control of educational achievements (Ephraim, 2003), control as a means of assessing the quality of specialist training in primary and secondary professional education (Sakowski, 2006), development of assessing the quality of training system (Permyakov, 2009). Discrete issue of forming and control foreign language speech skill with the help of computer-based learning program is considered in assessment of nonlinguistic students foreign language preparation area (Bitesheva, 2005), test verbal professionally oriented communication in a foreign language control (Zarutskaya, 2012), computer test as an assessing method of linguistic competence forming (Ovcharenko, 2007) and others.

The need to use professionally oriented situations and creative forms of control when checking and assessing intercultural communicative professional competence emphasizes as a result of the development of professionally oriented teaching foreign languages in universities of different profiles in several studies (Galustyan, 2008; Guseynova, 2008; Gutareva, 2005; Yevdokimova, 2007; Koryakovtseva, 2011; Matiyenko, 2009; Tenishheva, 2008; Khomyakova, 2011, Yarotskaya, 2013). It sets about development and enrichment of the assessment tools funds with help of the use of new control forms and students competence forming assessment in the field of foreign language.

Foreign researchers in contexts comparable with the situation of control, often use the terms testing, evaluation and assessment (J. Alderson, 
L. Bachman, G. Bick, L. Bond, T. Brian, M. Byram, M. Canale, D. Douglas, R. Ellis, A. Green, J. Heaton, A. Hughes, D. Nutall, M. Poehner, R. Riley, E. Shohamy, B. Spolsky, M. Swain, W. Taylor, N. Underhill, C. Weir and others). It is important to keep in mind that the existing in the Russian language two different terms "control" (which the majority of Russian authors, as a rule, minimizes to a notion "examine") and "management" (which tool is the control) corresponds to one word "control".

Moreover, the structure of the meaning of this English word "adjustment" and "management" also is not differentiated, that only exacerbates the situation for the Russianspeaking researchers to the problem of control, used to actively operate the above terms. In the opinion of L.V. Yarotskaya, it is necessary to take into account the fact that control in special English discourse nearly always implies control, and, as a rule, hard, and, consequently, in a different context, there is no special comment to be used as the English equivalent of the existing in domestic didactics of the concept of "control" (Yarotskaya, 2011: 8).

\section{Methods}

The most important criterion in assessing is relevance. Although teachers are ideally placed to provide accurate assessments of student performance, students can also be extremely effective at monitoring and judging their own language production.

Self-assessment is a competence central to purposeful action and meaningful reporting. It belongs to an assessment culture with a wide range of assessment strategies and formats, including third-party assessment, examination and tests. Self-assessment may lack face-validity and reliability in high-stakes situations, yet it is relevant in assessing opportunities, requirements, one's own strengths, and the potential benefits of deciding whether, when and how to act in particular situations.

Appropriate self-assessment can be decisive for success in educational settings and beyond in real-life situations. It should be noted that regular opportunities for assessment and teacher guidance are crucial if learners are to develop the capacity to adequately gauge their linguistic, communicative and inter-cultural competences (Bachman, 1996: 87). Self-assessment can be made in a number of ways. For example, at the end of a course book unit a teacher may ask student to check what they can now do, e.g. Now I know how to report by means of Past Tenses.

This kind of self-assessment is at the heart of the "can do" statements from ALTE (Association of Language Testers in Europe) and the Common European Framework (CEF). Students in many different languages - can measure themselves by saying what they can do in various skill areas. The ALTE statements for general overall ability (giving six levels from A1-C2), give students clear statements of ability against which to measure themselves (Table 1).

Currently, in terms of the Russian academic excellence program mock exams have been widely used in Siberian Federal University during teaching English to students of nonlinguistics specialties. This fact can be easily explained by the main goal of the program: students have to take international exams, such as Preliminary English Test (PET), First Certificate in English (FCE) and Test of Legal English Skills (TOLES). Since 2016, over 200 students of non-linguistics specialties have been trained and prepared for international exams conducted by Cambridge ESOL (University of Cambridge Local Examinations Syndicate). Due to such methods of research as prognostic simulation and experimental learning the author collected data connected with the system of evaluating students' progress by means of mock 
Table 1. Overall general ability of ALTE levels

\begin{tabular}{|c|c|c|c|}
\hline LEVELS & Listening/Speaking & Reading & Writing \\
\hline $\begin{array}{l}\text { C2 } \\
\text { Level } 5\end{array}$ & $\begin{array}{l}\text { CAN advise on or talk about } \\
\text { complex or sensitive issues, } \\
\text { understanding colloquial references } \\
\text { and dealing confidently with hostile } \\
\text { questions }\end{array}$ & $\begin{array}{l}\text { CAN understand } \\
\text { documents, correspondence } \\
\text { and reports, including the } \\
\text { finer points of complex texts }\end{array}$ & $\begin{array}{l}\text { CAN write letters on any } \\
\text { subject and full notes of } \\
\text { meeting or seminars with } \\
\text { good expression or accuracy }\end{array}$ \\
\hline $\begin{array}{l}\text { C2 } \\
\text { Level } 4\end{array}$ & $\begin{array}{l}\text { CAN contribute effectively to } \\
\text { meetings and seminars within own } \\
\text { area of work or keep up a casual } \\
\text { conversation with a good degree } \\
\text { of fluency, coping with abstract } \\
\text { expressions }\end{array}$ & $\begin{array}{l}\text { CAN read quickly enough } \\
\text { to cope with an academic } \\
\text { course, to read the media } \\
\text { for information or to } \\
\text { understand non-standard } \\
\text { correspondence }\end{array}$ & $\begin{array}{l}\text { CAN prepare / } \\
\text { draft professional } \\
\text { correspondence, take } \\
\text { reasonably accurate notes in } \\
\text { meetings or write an essay } \\
\text { which shows an ability to } \\
\text { communicate }\end{array}$ \\
\hline $\begin{array}{l}\text { B2 } \\
\text { Level } 3\end{array}$ & $\begin{array}{l}\text { CAN follow or give a talk on } \\
\text { a familiar topic or keep up a } \\
\text { conversation on a fairly wide range } \\
\text { of topics }\end{array}$ & $\begin{array}{l}\text { CAN scan texts for relevant } \\
\text { information, and understand } \\
\text { detailed instructions and } \\
\text { advice }\end{array}$ & $\begin{array}{l}\text { CAN make notes while } \\
\text { someone is talking or write } \\
\text { a letter including non- } \\
\text { standard requests }\end{array}$ \\
\hline $\begin{array}{l}\text { B1 } \\
\text { Level } 2\end{array}$ & $\begin{array}{l}\text { CAN express opinions on abstract/ } \\
\text { cultural matters in a limited way or } \\
\text { offer advice within a known area, } \\
\text { and understand instructions and } \\
\text { public announcements }\end{array}$ & $\begin{array}{l}\text { CAN understand routine } \\
\text { information and articles, } \\
\text { and the general meaning } \\
\text { of non-routine information } \\
\text { within a familiar area }\end{array}$ & $\begin{array}{l}\text { CAN write letters or } \\
\text { make notes on familiar or } \\
\text { predictable matters }\end{array}$ \\
\hline $\begin{array}{l}\text { A2 } \\
\text { Level } 1\end{array}$ & $\begin{array}{l}\text { CAN express simple opinions or } \\
\text { requirements in a familiar context }\end{array}$ & $\begin{array}{l}\text { CAN understand } \\
\text { straightforward information } \\
\text { within a known area, such } \\
\text { as on products and signs and } \\
\text { simple textbooks or reports } \\
\text { on familiar matters }\end{array}$ & $\begin{array}{l}\text { CAN complete forms and } \\
\text { write short simple letters or } \\
\text { postcards related to personal } \\
\text { information }\end{array}$ \\
\hline $\begin{array}{l}\text { A1 } \\
\text { ALTE } \\
\text { Break- } \\
\text { through } \\
\text { level }\end{array}$ & $\begin{array}{l}\text { CAN understand basic instructions } \\
\text { or take part in a basic factual } \\
\text { conversation on a predictable topic }\end{array}$ & $\begin{array}{l}\text { CAN understand basic } \\
\text { notices, instructions or } \\
\text { information }\end{array}$ & $\begin{array}{l}\text { CAN complete basic forms, } \\
\text { and write notes including } \\
\text { times, dates and places }\end{array}$ \\
\hline
\end{tabular}

exams. Students' command of language is determined by the entrance test. Students, who show best results, enter preparation group for FCE (First Certificate in English) exam, which corresponds to B2 level, Preliminary English Test (PET) corresponds to B1 level according to The Common European Framework of Reference for Languages (CEFR).

The training program and Cambridge ESOL advance language skills, allow the certificate holder to communicate in English in a variety of situations of real communication without assistance. At the end of practice oriented course, students are familiar with the format of international exams and the most effective techniques of task performance; able to perform the typical tasks for each of the 4 sections in accordance with time limits set by the exams; are familiar with the typical examination vocabulary.

Such control method allows (Burgess, Head, 2006: 124):

1) Students to familiarize themselves with exam procedure: by filling in the answer sheet, time limits, issues that candidates may obtain during the exam;

2) Identify more successful and less successful students, strategies that need to be developed for passing an exam; 
3) Obtain a real exam experience that will help the student to overcome nervousness before the "real" exam;

4) Control the level of proficiency on the studied linguistic material, which gives the opportunity to adjust the curriculum, to repeat certain themes.

It's important to notice that the key item of such control type is academics behavior, who acts as "an examiner", in other words, should strictly follow the examination procedures, to monitor the time required to perform tasks, assess the test papers according to the criteria pre-known by students strictly. These conditions are toughened in the case of the trial of international exams.

\section{Conclusion}

According to results presented in the article we may state that such method of alternative control as a mock exam promotes a learner-centered, communicative and inclusive approach to language learning in a lifelong perspective, fostering learner autonomy and independent learning, contributing to coherence and continuity in educational process. This method also helps to promote transparent descriptions of language competence and qualifications, skills and abilities of students. Research outcomes obtained as a result of Russian academic excellence program show that alternative methods of control may be a means of converting the situation of educational measurement in a training situation, if they help students to understand the results of their learning activities better, to identify the causes of successes and failures, and use the findings to improve the effectiveness of their own studying.

Analysis of mock exams is useful for all participants of pedagogical process as it provides objective information, including the achieved command of language, the dynamics of the demonstrated results and progress, as well as the communicative abilities of the students and cognitive difficulties.

\section{References}

Setting standards sustaining diversity. In ALTE. Available at: http://www.alte.org/can_do/general.php Alderson, J. (1995). Language Test Construction, and Evaluation. Cambridge, Cambridge University Press, 275 p.

Anderson, L.W., Krathwohl, D.R., Airasian, P.W., Cruikshank, K.A., Mayer, R.E., Pintrich, P.R., Raths, J., Wittrock, M.C. (2001). A Taxonomy for Learning, Teaching, and Assessing: A Revision of Bloom's Taxonomy of Educational Objectives. New York: Pearson, Allyn \& Bacon, available at: https://www.scopus.com

Bachman, L. (1990). Fundamental Considerations in Language Testing. Oxford, Oxford University Press, 385 p.

Bachman, L. (1996). Language Testing in Practice: designing and developing useful language tests. Oxford, Oxford University Press, 377 p.

Bond, L. (1996). Norm - and criterion-referenced testing. In Practical Assessment, Research and Evaluation, 5(2), 11-23.

Brian, T. (2005).Testing to learn: a personal view of language testing. In ELT Journal. Oxford, Oxford University Press, 59(1), 39-46.

Burgess, S., Head, K. (2006). How To Teach Exams. Pearson, 157 p.

Byram, M. (1997). Teaching and Assessing Intercultural Communicative Competence. Clevedon, Multilingual Matters, $587 \mathrm{p}$. 
Cheah, Ch. Y.J., Chen, P.H., Ting, S.K. (2005). Globalization challenges, legacies, and civil engineering curriculum reform. In Journal of Professional Issues in Engineering Education and Practice, 131 (2), 105-110.

Douglas, Dan. Understanding Language Testing. Routledge, 2010, 156 p.

Marianne, C.M. (2001). Discourse and context in language teaching. Cambridge University Press, $288 \mathrm{p}$.

Roadmap for the Competitiveness Enhancement Program of Siberian Federal University, for the period 2016-2020 (Stage 1 - 2016-2018). In Official site of SFU. Available at: http://about.sfu-kras.ru/ node/9719

Sergeyeva S.V., Voskrekasenko O. A. (2016). Formirovanie sotsial'nykh kompetentnostei obuchaiushchikhsia $\mathrm{v}$ tekhnicheskom vuze kak mnogourovnevom obrazovatel'nom komplekse [The formation of students' social competences in a technical university as a multilevel educational complex]. In integratsiya obrazovaniya [Integration of Education], 20(4), 484-492. DOI:10.15507/19919468.085.020.201604.484-492. Thornbury, S. (2005). How to Teach Speaking. Pearson, 157 p.

Yarotskaya, L.V. (2011). Kontrol v produktivnoi paradigm lingvistiki. [Control in the productive paradigm of linguistics]. Saarbrüchen: LAP, $179 \mathrm{p}$.

Yarotskaya, L.V. (2016). Inostrannii yazik i stanovleniye profesionalnoi lichnocti (neyayikovoi vuz) [Foreign language and becoming a professional individual (non-linguistics Higher School)]. Moscow, Triumf, $179 \mathrm{p}$.

\title{
Иностранный язык в нелингвистическом вузе: оптимальные методы контроля
}

\author{
В.В. Воног \\ Сибирский федеральный университет \\ Россия, 660041, Красноярск, пр. Свободный, 79
}

\begin{abstract}
Статья посвящена авторским наблюдениям и исследованию, целью которых является поиск метода контроля, соответствующего индивидуальному подходу к студенту в проиессе преподавания английского языка в вузе. Целевой аудиторией выступают студенты нелингвистических спечиальностей, которых готовят к экзаменам Кембриджского синдиката в рамках программы повышения конкурентоспособности ведущих российских университетов. Усилия Сибирского федерального университета направлены на увеличение аудиторных часов дисииплины «Иностранный язык» и организацию системы внутренней и внешней аттестации, а именно таких международных экзаменов, как Кембриджские экзамены на получение свидетельства по английскому языку и международный экзамен по юридическому английскому. Благодаря таким методам, как прогнозирующее моделирование и опытное обучение, автор работы получила данные о системе оиенивания прогресса знаний студентов с помощью пробных экзаменов, выбор которых обоснован повышением качества и эффективности преподавания и увеличением мотивации среди студентов нелингвистических специальностей, а также сокращением времени на достижение определенных результатов.
\end{abstract}


Ключевые слова: метод контроля, английский язык, пробный экзамен, экзамены Кембриджского синдиката, программа повыщения конкурентоспособности ведущих российских универcuтетов.

Научная специиальность: 13.00.08 - теория и методика профессионального образования. 